\title{
Структура та зміст фітнес-програми з елементами спортивних танців для дітей старшого дошкільного віку
}

\section{Анастасія Чеверда, Петро Мартин}

$$
\text { Національний університет фізичного виховання і спорту України, Київ, Україна }
$$

Анотація. У статті науково обґрунтовано, розроблено та перевірено ефективність фітнес-програми для дітей старшого дошкільного віку з елементами спортивних танців, спрямованої на підвищення показників їх фрізичного стану. Мета. Розробити структуру і зміст фрітнес-програми, спрямованої на підвищення показників фрізичного стану дітей старшого дошкільного віку. Методи. Теоретичний аналіз і узагальнення науково-методичної літератури, аналіз вітчизняного та зарубіжного досвіду, документальних матеріалів; педагогічні; антропометричні; фрізіологічні методи дослідження; методи математичної статистики. Результати. Дослідження проводили на базі клубу спортивного танцю «Супаданс» У дослідженні брали участь 45 дітей старшого дошкільного віку. Програма містила кілька блоків (хореографічний, коригувальний, ігровий, танцювальний та змагальний), спрямованих на покращення постави дітей, підвищення їхньої фрізичної підготовленості, формування мотивації до регулярних занять руховою активністю, дотримання рекомендацій з ведення здорового способу життя, естетичне виховання. Програма містила такі структурні компоненти: використання базових та допоміжних фігур спортивного танцю; застосування засобів і методів оздоровчого фітнесу, доступних для старших дошкільнят, для підвищення ефективності навчання танцювальних рухів; критерії результативності. На кожному етапі програми було застосовано адекватні методи лікарсько-педагогічного контролю, які дозволили здійснювати моніторинг показників фізичного стану та в разі потреби - вносити корективи. Ефективність запропонованої програми доведено за результатами перетворювального педагогічного експерименту за показниками фрізичного стану дітей старшого дошкільного віку.

Ключові слова: дитячий фітнес, діти 5-6 років, програма, блочний принцип, контроль.

\section{Anastasia Cheverda, Petro Martyn}

\section{THE STRUCTURE AND CONTENT OF THE FITNESS PROGRAM WITH ELEMENTS OF SPORTS DANCE FOR OVER-FIVES}

Abstract. The article scientifically substantiates, develops and tests the effectiveness of a fitness program for over-fives with elements of sports dances, aimed at improving their physical condition. Objective. Develop the structure and content of a fitness program aimed at improving the physical condition of over-fives. Methods. Theoretical analysis and generalization of scientific and methodical literature, analysis of domestic and foreign experience, documentary materials; pedagogical; anthropometric; physiological research methods; methods of mathematical statistics. Results. The research was conducted on the basis of the sports dance club «Supadans». The study involved 45 over-fives. The program contained several blocks (choreographic, corrective, playful, dance and competitive), aimed at improving the posture of children, their physical fitness, forming motivation for regular physical activity, following the recommendations for a healthy lifestyle, aesthetic education. The program contained the following structural components: the use of basic and auxiliary figures of sports dance; the use of means and methods of health fitness, available for over-fives to increase the effectiveness of learning dance movements; performance criteria. At each stage of the program, adequate methods of medical and pedagogical control were applied, which allowed to monitor the indicators of physical condition and, if necessary, to make adjustments. The effectiveness of the proposed program is proved according to the results of a transformational pedagogical experiment and the indices of the physical condition of over-fives.

Keywords: children's fitness, children aged 5-6, program, block principle, control.

Cheverda A., Martyn P. The structure and content of the fitness program with elements of sports dance for over-fives. Theory and Methods of Physical education and sports. 2021; 1 : 63-68

DOI: 10.32652/tmfvs.2021.1.63-68
Чеверда А, Мартин П. Структура та зміст фітнес-програми з елементами спортивних танців для дітей старшого дошкільного віку. Теорія і методика фрізичного виховання і спорту. 2021; 1 : 63-68

DOI: 10.32652/tmfvs.2021.1.63-68
Вступ. У Глобальній стратегії В003 з охорони здоров'я жінок і дітей зазначено, що «...інвестиції у здоров'я дітей мають високу економічну доцільність і забезпечують найкращу гарантію наявності продуктивної робочої сили у майбутньому». Проте, варто наголосити, що однією 3 найважливіших проблем сьогодення в Україні $€$ істотне погіршення стану здоров'я дітей, зокрема, старшого дошкільного віку, і постійне зниження рівня їх фрізичного стану. Дослідниками зазначається, що суттєвий вплив на поширеність захворювань серед дітей старшого дошкільного віку мають «хвороби цивілізації», а саме: залежність від «екранних» технологій, нездорове харчування, недостатня рухова активність [9]. У колі науковців особливе занепокоєння викликає підвищення рівня розумових навантажень у дітей дошкільного віку, залучених до підготовки в освітніх установах різного типу, що спрямовані на досягнення успіху в інтелектуальній діяльності, з одного боку, і погіршення стану здоров'я, обмеження рівня рухової активності, втрату ціннісних орієнтацій на здоровий спосіб життя - з іншого [7].

Дефріцит рухової активності дітей привертає значну увагу фахівців і батьків до цього питання, а також підкреслює масштабність проблеми недостатньої рухової активності дітей у цілому [5]. Зважаючи на це, залучення дітей старшого дошкільного віку до оздоровчо-рекреаційної рухової активності $€$ важливою проблемою державної політики. Проте протягом багатьох років спостерігається незадоволеність традиційними заняттями фрізичною культурою значної частини дітей, що позначається на зниженні рівня їхньої фрізичної підготовленості та втраті інтересу до занять [2, 4]. Зазначене актуалізує пошук ефективних шляхів оздоровлення і гармонійного розвитку дітей старшого дошкільного віку, підвищення рівня їхньої фрізичної підготовленості, фрор- 
мування інтересу до регулярних занять оздоровчо-рекреаційною руховою активністю.

Проведений аналіз спеціальної науково-методичної літератури свідчить про значний інтерес до розробки та впровадження інноваційних технологій у процес оздоровчих занять старших дошкільників, заснованих на різних видах рухової активності [1, $3,10,13]$. Особливо затребуваними $\epsilon$ технології, засновані на використанні елементів оздоровчого фрітнесу [6, 15]. Для даного контингенту одним із найпопулярніших видів рухової активності є спортивний танець $[11,12,14]$ Однак, використання елементів спортивного танцю у фрітнес-програмах для дітей старшого дошкільного віку обґрунтовано недостатньо. Зазначене обумовлює актуальність нашого дослідження.

Дослідження виконано відповідно до плану НДР НУФВСУ на 20212025 рр. за темою «Теоретичні та технологічнізасади оздоровчо-рекреаційної рухової активності та здорового способу життя різних груп населення» (номер держреєстрації 0121U107534).

Мета дослідження - розробити структуру і зміст фрітнес-програми 3 елементами спортивних танців для дітей старшого дошкільного віку, спрямованої на підвищення показників їхнього фрізичного стану, та оцінити їі ефективність.

Методи дослідження: теоретичний аналіз і узагальнення даних науковометодичної літератури, аналіз вітчизняного та зарубіжного досвіду, документальних матеріалів; педагогічні антропометричні, фрізіологічні методи дослідження; методи математичної статистики.

Результати дослідження та їх обговорення. Теоретичний аналіз науково-методичної літератури, узагальнення вітчизняного та зарубіжного досвіду практики в галузі фрізичного виховання дітей дошкільного віку, документальних матеріалів дозволили визначити актуальність дослідження, уточнити і конкретизувати мету, завдання і спрямованість педагогічних експериментів. Було застосовано метод спостереження за організацією, методикою занять і реакцією дітей, що дозволяє здійснювати візуальне оцінювання ефек- тивності. Перетворювальний експеримент був спрямований на оцінювання ефективності програми фітнесзанять 3 використанням засобів спортивних танців, тривалість його становила 9 місяців. У роботі застосовано статистичні методи дослідження: аналіз даних, отриманих в процесі педагогічного експерименту, що передбачав первинне вивчення отриманих емпіричних даних із використанням описової статистики, вибіркового методу; оцінку узгодженості отриманих даних закону нормального розподілу із використанням критерію згоди Шапіро-Уїлка. Визначення статистично значущих відмінностей між вибірками здійснювали на основі параметричних та непараметричних критеріїв на рівні значущост $\alpha=0,05(p<0,05)$. У дослідженні емпіричні дані, які підпорядковувались нормальному закону розподілу, представлено у вигляді середнього значення й стандартного відхилення $(x, \mathrm{~S})$, а інші - у вигляді медіани та 25 і 75-го персентиля (Me; 25 \%; 75 \%). Використання методів математичної статистики дозволило провести обробку емпіричних даних, сприяло їх інтерпретації, формулюванню висновків. Систематизацію матеріалу та первинну математичну обробку виконували із використанням програмних пакетів MS Excel (Microsoft, СШA), Statistica 8.0 (StatSoft, США). Дослідження проводили на базі клубу спортивного танцю «Супаданс». У дослідженнях брали участь 45 дітей старшого дошкільного віку (23 дівчинки та 22 хлопчики).

Програма оздоровчих занять 3 елементами спортивних танців розрахована на 108 год. Проведення таких оздоровчих занять має задовольнити оздоровчо-рекреаційні потреби дітей старшого дошкільного віку. Основною метою пропонованої програми є сприяння розвитку здорової гармонійно розвиненої особистості, організація корисного дозвілля та активного відпочинку, виховання позитивних моральних і вольових якостей. Участь у клубних змаганнях сприяє розвитку у дітей бажання вдосконалювати свої навички для одержання перемоги, фрормування стійкого інтересу до подальшого розвитку навичок у спортивних танцях. Фітнес-програма з елементами спортивних танців спря- мована на набуття первинних знань про зміст, ритми, особливість спортивних танців та вивчення основних базових кроків, зорієнтована на дитину, враховує її інтереси, спрямовується на гармонійне виховання творчої особистості (рис. 1).

Основними принципами, які покладено в основу розробки програми, були:

- сенситивності дошкільного віку для музично-рухового розвитку, єдності розвитку, освіти, виховання і навчання (своєчасність залучення дітей до хореографічної діяльності у дошкільному дитинстві; виявлення, підтримання і розвиток інтересу до мистецтва танцю; дитина розвивається, виховуючись і навчаючись; розвиваюче освітнє середовище сприяє розвитку дитини);

- ампліфрікації дитячого розвитку (збільшення можливостей розвитку через розширення дитячих мистецьких діяльностей за рахунок хореографрії)

- природовідповідності, актуалізації дитячої активності (врахування вікових можливостей, індивідуальних природних задатків, схильностей, потреб дошкільника, підтримання емоційно-пізнавальної активності, вольових зусиль дитини, її зацікавленості, ініціативності);

- гуманізації, демократизації та оптимізації педагогічного процесу (увага, повага, доброзичливість, турбота, любов до дитини; підтримання їі успішності, організація толерантного спілкування; створення оптимальних умов для хореографічної діяльності дітей тощо);

- особистісно зорієнтованого та індивідуально-диференційованого підходу до дитини під час навчання (орієнтування на особистісні, вікові особливості дітей, статеві відмінності хлопчиків і дівчаток, узгодження занять колективних, у підгрупах, у парах, індивідуальних);

- інтеграції, системності, орієнтування на психологічний вік, на основні сфери дійсності під час визначення змісту програми та шляхів їі реалізації в освітньо-виховному процесі [8].

Фітнес-програма 3 елементами спортивних танців побудована за блочним принципом і включає п'ять блоків: 


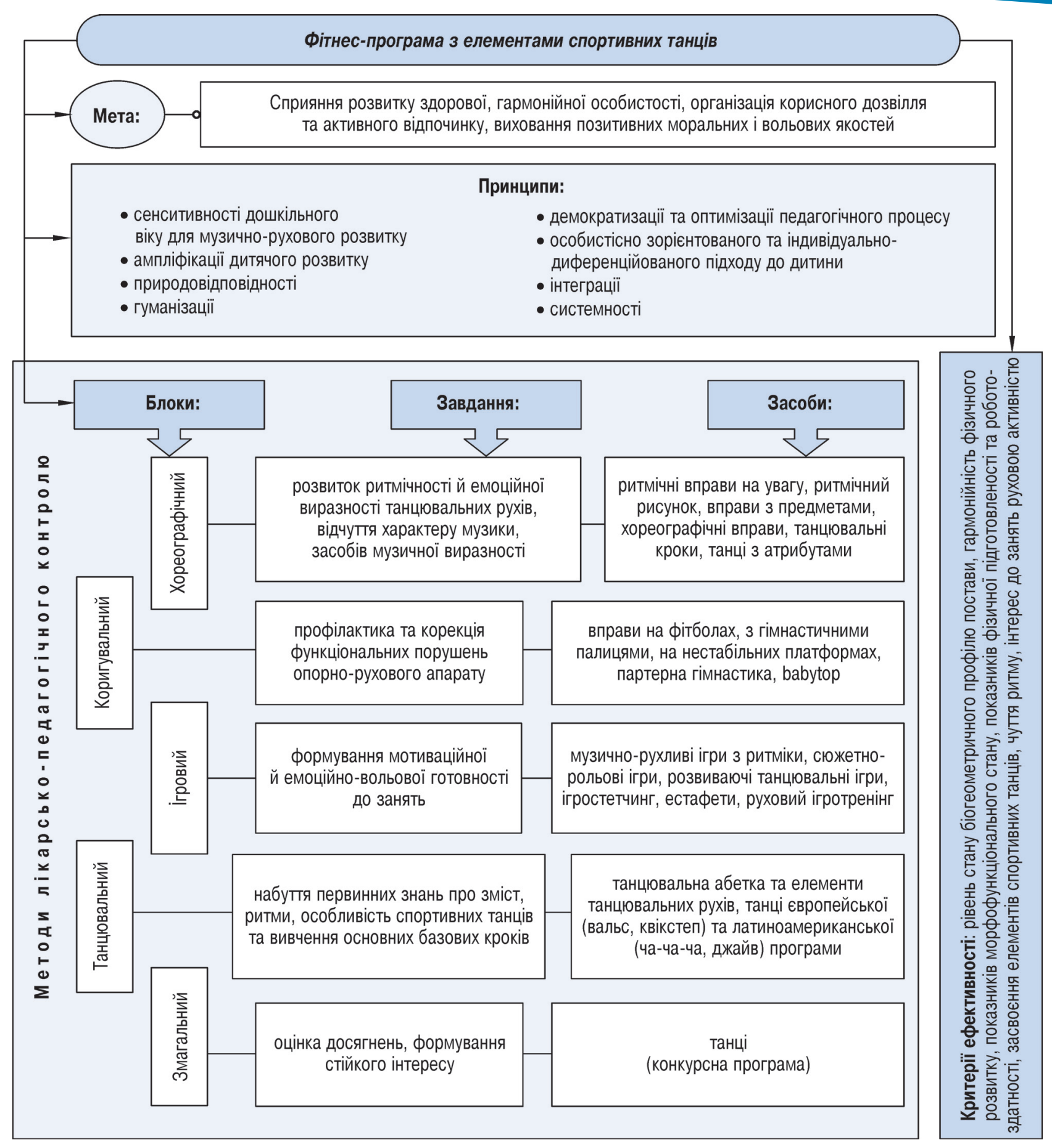

Рисунок 1 - Структура програми оздоровчих занять дитячим фрітнесом з елементами спортивних танців

хореографрічний, коригувальний, ігровий, танцювальний, змагальний.

Хореографрічний блок був спрямований на розвиток уміння ритмічно рухатися, відтворювати ритмічний малюнок танцю і хореографрічні образи; включав основи хореографічної грамотності, ритмічні вправи на увагу, ритмічний рисунок, вправи з предметами, хореографрічні вправи, танцювальні кроки, танці з атрибутами.
Коригувальний блок спрямований на формування правильної постави, гарної ходи, пластичність рухів, упевненість у собі, профілактику функціональних порушень опорнорухового апарату, плоскостопості. Цей блок передбачав використання вправ на фрітболах, з гумовими амортизаторами, вправи на нестабільних платсрормах, партерну гімнастику, babytop.
Ігровий блок був спрямований на формування мотиваційної й емоційновольової готовності, навчання регулювати свою поведінку відповідно до соціальних вимог, формування інтелектуальної готовності через ігри, спрямовані на розвиток психічних процесів. Спочатку ігрові технології використовували як окремі ігрові моменти, які дуже важливі, особливо в період адаптації дітей у колективі. Цей 
блок включав музично-рухливі ігри з ритміки, сюжетно-рольові ігри, розвиваючі танцювальні ігри, ігростетчинг, естафети, руховий ігротренінг.

Танцювальний блок включав танцювальну абетку та елементи танцювальних рухів, основи навчання танців латиноамериканської (ча-ча-ча, самба) та європейської програм (вальс, квікстеп).

Змагальний блок спрямований на формування стійкого інтересу до подальшого розвитку навичок у спортивних танцях, на оцінку досягнень, включав участь у клубних змаганнях.

На кожному етапі розробленої програми було застосовано методи лікарсько-педагогічного контролю, які дозволили здійснювати моніторинг показників фізичного стану та, в разі потреби, вносити корективи до програми

Результативність запропонованої програми розглядали в процесі перетворювального педагогічного експерименту на базі танцювального клубу «Супаданс», тривалість якого становила 9 місяців.

За результатами експерименту зафіксовано зміни в бік нормалізації співвідношення довжини й маси тіла для хлопчиків і дівчаток, що виявилися статистично значущими ( $p<0,05)$ Як засвідчив розподіл учасників експерименту, незалежно від статі зросла частка дітей $з$ нормальним співвідношення довжини й маси тіла: у дівчаток приріст становив 4,35\%, а в хлопчиків - 13,64\%. На 13,04 \% зросла частка дівчаток з гармонійними пропорціями тіла, а в хлопчиків - на 9,09 \%.

Рівень стану біогеометричного профрілю постави дітей старшого дошкільного віку статистично значуще $(p<0,05)$ підвищився у дівчаток на $16,39 \%$, у хлопчиків на 22,73\%.

Установлено позитивний вплив запропонованої програми на діяльність серцево-судинної системи (ССС) учасників експерименту. Так, частоти серцевих скорочень (ЧСС) дівчаток статистично значуще зменшилась $(\mathrm{p}<0,05)$ і становила 8,58 \%, тобто 84,$35 ; 6,00$ уд $\cdot$ хв$^{-1}$. У хлопчиків ЧСС статистично значуще $(p<0,05)$ скоротилася, її середньогрупове значення становило 83,05; 3,66 уд · хв ${ }^{-1}$. Виявлені зміни показників діяльності ССС обумовили статистично зна- чуще ( $<<0,05)$ зменшення величини індексу Робінсона: на 10,19 (усього на 9,29 ум. од.) і 7,71 \% (усього на 6,82 ум. од.) у дівчаток і хлопчиків відповідно, що свідчить про вдосконалення максимальних аеробних можливостей організму обстежених.

Відповідні позитивні зміни вдалося зареєструвати під час розподілу дітей за рівнем стану регуляції ССС Частка дівчаток з низьким рівнем скоротилася на 47,83 \%, натомість частка з вище середнього рівнем зросла на $26,08 \%$. У хлопчиків зросли частки 3 вище середнього та середнім рівнем регуляції стану ССС на 9,09 \% 45,49 \% відповідно за рахунок скорочення частки 3 нижчим середнього рівнем на $54,55 \%$.

Вдалося зафіксувати й сприятлив зрушення в показнику фрізичної роботоздатності дівчаток - індексу Руср'є, який наприкінці експерименту статистично значуще ( $<<0,05)$ зменшився на 21,9 \% (усього на 2,50 ум. од.) у хлопчиків статистично значуще $(p<0,05)$ покращення становило $20,2 \%$ (усього на 2,27 ум.од.). Такі результати обумовили збільшення частки дівчаток 3 вищим за середній рівнем на 17,39 \% та на 43,78 \% 3 середнім рівнем фрізичної роботоздатності за рахунок скорочення відсотка дівчаток, які характеризувалися нижчим за середній й низьким рівнями фрізичної роботоздатності на 47,83 \% і 13,04\% відповідно.

Статистична обробка емпіричного матеріалу показала, що внаслідок застосування авторської програми у дітей незалежно від статі статистично значуще $(p<0,05)$ зменшилося значення показника адаптаційного потенціалу (АП), що вказує на підвищення рівня адаптаційних резервів організму учасників експерименту. Так, у дівчаток АП знизився на 7,89 \%, а в хлопчиків - на 5,54 \% і наприкінці експерименту середньогрупові оцінки АП відповідно становили 1,66; 0,13 та 1,67; 0,11 ум. од.

Час затримки дихання в проб Штанге статистично значуще $(p<0,05)$ збільшився на 10,6 \% (всього 1,52 с) й становив 15,91; 1,90 с, а час затримки дихання в пробі Генчі - на 8,75 \% (усього 1,0 с), після експерименту становив 12,$43 ; 1,47$ с., що також свідчить про статистично значуще $(p<0,05)$ покрашення стану дихальної системи учасниць експерименту. у хлопчиків відбулися такі позитивні статистично значущі $(p<0,05)$ зміни: час затримки дихання у пробі Штанге зріс на 7,06 \% (всього 1,09 с) й становив 16,55; 1,44 с, а у пробі Генчі - на $6,57 \%$ (усього 0,82 с), після експерименту становив 13,27; 1,24 с.

Унаслідок позитивних змін, що простежувалися за показниками фрізичного стану, після експерименту в дітей 5-6 років відбулися позитивні зрушення величини показника АРМ. Так, після експерименту загальна оцінка АРМ дівчаток статистично значуще зросла $(p<0,05)$ на 42,60\% (усього 0,67 ум. од.) й становила 2,23; 0,59 ум. од. Частки дітей з високим та середнім рівнем АРМ збільшились на $30,43 \%$ і 26,09 \%, тоді як частки дітей з низьким і критично низьким рівнем АРМ зменшилися на 39,13\% і 17,39 \% відповідно. Загальна оцінка АРМ хлопчиків статистично значуще $(\mathrm{p}<0,05)$ зросла на 28,20 \% (усього 0,50 ум. од.) й становила 2,27; 0,42 ум. од. При цьому відсоток хлопчиків з високим та середнім рівнями АРМ збільшився на 31,82 \% і 22,73 \% відповідно за рахунок скорочення частки 3 низьким і критично низьким рівнями APM на 36,36 \% і 18,18\%. Після експерименту хлопчиків 3 критично низьким АРМ не виявлено.

Позитивними були також зміни й у показниках фрізичної підготовленості дітей старшого дошкільного віку. Сила м'язів ніг та швидкісно-силові здібності обстежених дітей за період експерименту суттєво зросли. Наприкінці експерименту в них статистично значуще $(p<0,05)$ збільшилася кількість разів, коли дівчатка, так само як і хлопчики, в стрибку змогли торкнутися предмета. Так, медіанне значення незалежно від статі після експерименту зросло від 1; 2; 2 до 2; 2; 3 разів, де спостережувані дані представлено у вигляді медіани й 25 та 75 процентилів (Мe, $25 \%, 75 \%$ ), що свідчить про підвищення в учасників дослідження сили м'язів ніг та вміння стрибати. Щодо оцінки швидкісно-силових здібностей за стрибком у довжину з місця, то після експерименту зафріксовано статистично значуще збільшен- 
ня середньостатистичних показників у дівчаток і хлопчиків $(p<0,05)$. Так, довжина стрибка в дівчаток зросла на 18,39 см до 124,52; 7,41 см і загалом приріст становив 17,33 \%, а приріст у хлопчиків становив 7,25\% і средньостатистичний показник досяг 125,73; $5,81 \mathrm{~cm}$.

Ефективність запропонованої технології проявилась під час оцінювання координаційних здібностей дітей за тестом Бондаревського до і після експерименту. У дітей виявлено статистично значущі прирости середнього показника в тесті із заплющеними очима, який становив 6,83\% і $4,33 \%$ у дівчаток і хлопчиків відповідно ( $p<0,05)$. Крім того статистично значуще збільшився $(p<0,05)$ час утримання статичної пози з розплющеними очима у дівчаток на 2,69 \%, а у хлопчиків - на 8,41 \%.

Розподіл дітей за рівнями гнучкості продемонстрував позитивний вплив запропонованої програми на стан рухливості хребта. Після експерименту в дітей статистично значуще зросла ( $p<0,05)$ оцінка рухливості хребта під час виконання нахилу вперед до 4,13; 0,63 см і 4,09; 0,61 см у дівчаток і хлопчиків відповідно. Усього прирости середніх показників становили 7,95 \% та 11,10\%. При цьому приріст оцінки рівня гнучкості під час нахилу назад у дівчаток становив $7,23 \%$, середня величина якого зафіксована на рівні 3,87; 0,63 бала, а в хлопчиків - 8,11 \% й середній показник досяг 3,64; 0,73 бала. Попри відсутність статистично значущого покращення, спостерігалася позитивна динаміка ( $p>0,05)$. Як бачимо, частка дівчаток з високим рівнем рухливості хребта під час нахилу вперед зросла на 13,04 \%, а під час нахилу назад - на 8,69 \%. Водночас збільшився відсоток дівчаток, які характеризуються середнім рівнем гнучкості: під час нахилу вперед - на 4,35 \%, а під час нахилу назад - на 8,70 \%. Частка хлопчиків із високим рівнем рухливості хребта під час нахилу вперед зросла на 22,70 \%, а під час нахилу назад - на 9,09 \% за рахунок скорочення частки дітей з низьким рівнем.Важливим для нашого дослідження стало удосконалення показників спеціальної фрізичної підготовленості в дітей, які брали участь у експерименті. Після його завершення виявлено частку дітей, які характеризуються високим рівнем витривалості під час виконання хореографічної зв'язки танцю ча-ча-ча у темпі музики: у дівчаток цей показник становив 8,7 \%, а в хлопчиків - 4,55 \%. Після експерименту в жодного не зафіксовано низького рівня витривалості.

Встановлено, що після експерименту поряд зі скороченням відсотка 3 поганим на 4,35 \% та 17,39\% збільшилась частка дівчаток з добрим та задовільним чуттям ритму, а приріст хлопчиків з доброю оцінкою чуття ритму становив 22,73 \%. Й хоча не підтверджено, що ці зміни є статистично значущими ( $p>0,05)$, простежується позитивна динаміка.

Розподіл дівчаток за рівнем швидкісних здібностей під час виконання спеціальної хореограсії засвідчив сприятливий вплив авторської програми. Як показали розрахунки, частки дівчаток, які відмінно й добре виконали основний рух ча-ча-ча в темпі 30 тактів за 1 хв, зросли на 8,70\% у кожному з випадків за рахунок скорочення часток із задовільним і незадовільним результатом. При цьому після експерименту основний рух «джайву» на місці відмінно і добре виконали відповідно на 13,04 \% і 4,35 \% більше дівчаток порівняно з початком експерименту. Частки хлопчиків, які мають відмінні швидкісні здібності, після експерименту за тестовими вправами «ча-ча-ча» і «джайв» у обох випадках зросли на 9,09\%.

Також запропонована програма позитивно вплинула на результати виконання спеціальної хореографії для визначення рівня розвитку координаційних здібностей. З'ясувалося, що після експерименту частка дівчаток, які відмінно й добре виконали фрігури в повільному вальсі, зросла на 13,04 \% у обох випадках. При цьому частки дівчаток, які продемонстрували задовільний та незадовільний результат, скоротилися на 17,39 \% та 8,70 \% відповідно. Разом 3 тим, на $17,39 \%$ і 8,70 \% збільшилися частки дівчаток, які показали високий та добрий результат під час виконання фігур квікстепу. Обробка експериментального матеріалу підтвердила статистично значуще зростання коорди- наційних здібностей під час виконання обох тестових вправ $(p<0,05)$. Серед хлопчиків також спостерігались прирости часток з відмінними й добрими результатами під час виконання фрігур у повільному вальсі та квікстепі.

Отримані результати дають підстави вказати на ефективність авторської програми й доводять адекватність застосовуваних засобів, а також дозволяють її рекомендувати для впровадження у практику роботи фрітнес-центрів, танцювальних клубів, закладів позашкільної освіти.

Дискусія. В результаті проведених досліджень підтверджено дані науковців про значний інтерес до розробки та впровадження інноваційних технологій у процес оздоровчих занять старших дошкільників, заснованих на різних видах рухової активності (Н. В. Москаленко, О. М. Демідова, 2016; В. В. Петрович, 2010; Р. О. Сухомлинов, 2020; П. О. Чередниченко, 2018), значну популярність засобів оздоровчого фітнесу (М. В. Антипина, 2019; В. В. Борисова зі співавт., 2019; Н. Э. Власенко, 2019; А. А. Нечитайлова, Н. С. Полунина, М. А. Архипова, 2017; 0. Г. Сайкіна, 2009; 0. А. Томенко, А. Ю. Старченко, 2016), зокрема спортивних танців серед дитячого контингенту (D. Chatzopoulos, G. Doganis, I. Kollias, 2018).

Отримали подальший розвиток наявні напрацювання (0. Калужна, І. Соронович, 2016; 0. В. Мартиненко, 2014; Н. Москаленко, 0. Демідова, В. Бодня, 2019; А. С. Шевчук, 2011; Л. Н. Эйдельман, 2012) з організації оздоровчих занять 3 дитячим контингентом в умовах танцювальних клубів та фрітнес-центрів на основ комплексного використання традиційних та інноваційних засобів оздоровчого фрітнесу та спортивних танців для підвищення рівня фрізичного здоров'я, покращення рівня стану біогеометричного просрілю постави, фрізичної підготовленості дітей старшого дошкільного віку.

До нових результатів роботи належить теоретичне обґрунтування фітнес-програми 3 елементами спортивного танцю для дітей старшого дошкільного віку, яка містить п'ять блоків (хореограсрічний, коригувальний, ігровий, танцювальний, змагальний); 
встановлення взаємозв'язку між заняттями батьків оздоровчим фрітнесом та їх стимулюванням дітей до оздоровчих занять з елементами спортивного танцю.

Висновки. Теоретично обґрунтовано та розроблено програму оздоровчих занять дитячим фотнесом з використанням засобів спортивних танців. Програма містила кілька блоків (хореографічний, коригувальний, ігровий танцювальний та змагальний), спрямованих на покращення постави дітей старшого дошкільного віку, підвищення результатів фрізичної підготовленості, формування мотивації дітей до регулярних занять руховою активністю, дотримання рекомендацій із ведення здорового способу життя, естетичне виховання. На кожному етапі розробленої програми було застосовано адекватні методи лікарсько-педагогічного контролю, що дозволило здійснювати моніторинг показників фрізичного стану та в разі потреби вносити корективи у програму. Есективність розробленої програми оцінена у педагогічному експерименті, тривалість якого становить 9 місяців.

Конфлікт інтересів. Автори заявляють, що відсутній будь-який конфрлікт інтересів.

\section{ЛITЕРАТУРА}

1. Андрєєва 0, Сухомлинов Р. Організація оздоровчо-рекреаційної рухової активност дітей дошкільного віку в умовах клубних занять. Теорія і методика фізичного виховання і спорту. 2016;3:29-32.

2. Андрєєва 0, Сухомлинов Р. Чинники що лімітують залучення дітей дошкільного віку до оздоровчо-рекреаційної рухової активності. В: Огаренко ВМ та ін., редактори. Актуальн проблеми фрізичного виховання, реабілітації, спорту і туризму: тези доп. 6-ї Міжнар. наук. практ. конф.; 2016 Жовт 20-21; Запоріжжя. Запоріжжя: КПУ; 2016. С. 150-1.

3. Андрєєва ОВ. Розробка та впровадження технології проектування активної рекреаційної діяльності різних груп населення. Спортивний вісник Придніпров'я. 2015;1:4-9.

4. Кашуба В, Носова Н, Коломієць Т, Бондар 0, Лісовський Б. Апробація карти скринінг контролю біогеометричного профілю поста ви дітей дошкільного віку в процесі фізично реабілітації. Вісник Прикарпатського університету. 2019;34:45-52.

5. Пангелова Н€. Формування гармонійно розвиненої особистості дітей дошкільного віку в процесі фрізичного виховання: [монографія] Переяслав-Хмельницький: ФОП Лукашевич 0. М.; 2013. 432 с

6. Томенко ОА, Старченко АЮ. Фізкультурна освіта старших дошкільнят: інноваційна технологія [монографія]. Суми: Вид-во; 2016. $169 \mathrm{c}$.

7. Чаговець Al. Гармонійне виховання дітей у культурно-освітньому просторі закладу дошкільної освіти: методологія, теорія, практика: монографія. Харків: ТОВ «ДІСА ПЛЮС» 2018. 348 c.

8. Шевчук АС. Дитяча хореографія : програ ма та навч.-метод забезпечення хореографічної. діяльності дітей від 3 до 7 років : навч.-метод. посіб. Київ : Шкільний світ; 2011. 128 с.

9. Юрчук 0. Вплив рухового режиму на фізичний стан дітей дошкільного віку. Нова педагогічна думка. 2017;2(90):64-8.

10. Andrieieva OV, Sainchuk OM. Approach to evaluating health level and adaptation possibilities in schoolchildren. Pedagogics, psychology, medical-biological problems of physica training and sports. 2014;2:3-8. doi: 10.6084/ m9.figshare.923507

11. Aubert S, Barnes JD, Abdeta C, Nader PA Adeniyi AF, Aguilar-Farias N, Tremblay MS et al. Global Matrix 3.0 Physical Activity Report Card Grades for Children and Youth: Results and Analy sis from 49 Countries. Journal of Physical Activity and Health. 2018;15:215-273. DOI: 10.1123 jpah.2018-0472

12. Chatzopoulos D, Doganis G, Kollias Effects of creative dance on proprioception, rhythm and balance of preschool children Early Child Dev Care. 2018;189:1943-53. DOI 10.1080/03004430.2017.1423484

13. Dos Santos GC, do Nascimento Queiroz J, Reischak-Oliveira Á, Rodrigues-Krause J. Effects of dancing on physical activity levels of children and adolescents: a systematic review. Complementary Therapies in Medicine. 2021;56:102586. DOI: 10.1016/j.ctim.2020.102586

14. Schroeder K, Ratcliffe S, Perez A, Earley D, Bowman C, Lipman TH. Dance for health: An intergenerational program to increase access to physical activity. J Pediatr Nurs. 2017;37:29-34. DOl: 10.1016/j.pedn.2017.07.004

15. Sekendiz B. FIT FOR KIDS. ACSM's Health \& Fitness Journal. 2018:22:33-6. DOI: 10.1249/ FIT.0000000000000382

\section{ІНФОРМАЦІЯ ПРО АВТОРІВ}

Чеверда Анастасія Олегівна https://orcid.org/0000-0001-9426-6608, trofimo4ka92@gmail.com Національний університет фізичного виховання і спорту України 03150, Київ, вул. Фізкультури, 1

\section{INFORMATION ABOUT THE AUTHORS}

Cheverda Anastasiia https://orcid.org/0000-0001-9426-6608, trofimo4ka92@gmail.com National University of Ukraine on Physical Education and Sport 03150, Kyiv, Fizkul'tury str., 1

\section{LITERATURE}

1. Andreieva 0, Sukhomlinov R. Organization of health-related and recreational motor activity of preschool children in the conditions of club classes. Teoriia i metodyka fizvykhovannia i sportu. 2016;3:29-32.

2. Andreieva 0, Sukhomlinov R. Factors limiting preschool children involvement to healthrelated and recreational activity. In: Oharenko VM et al., editors. Urgent issues of physical education, rehabilitation, sport and tourism: Materialy 6 nauch.-prakt. konf.; 2016 0ct 20-21; Zaporizhzhia: KPU; 2016. P. 150-1.

3. Andreieva 0. Development and introduction of technology of projecting active recreational activity of different population groups. Sportyvnyi visnyk Prydniprovia. 2015:1:4-9.

4. Kashuba V, Nosova N, Kolomiiets T, Bondar 0 , Lisovskyi B. Approbation of the screening control of the biogeometric profile of the posture of preschool children in the process of physical rehabilitation. Visnyk Prykarpatskoho universytetu. 2019:34:45-52

5. Pangelova NI._Formation of harmoniously developed personality of preschool children in the process of physical education: [monograph] Pereyaslav-Khmelnytsky: FOP Lukashevych 0. M.; 2013. $432 \mathrm{p}$

6. Tomenko 0, Starchenko A. Physical culture education of over-fives: innovation technology [treatise]. Sumy: Vyd-vo; 2016. 169 p.

7. Chahovets $A$. Harmonious upbringing of children in the cultural and educational space of preschool education: methodology, theory, practice: monograph. Kharkiv: DISA" PLUS LLC"; 2018. 348 p.

8. Shevchuk A. Children's choreography: program and teaching method of choreographic support. activities of children from 3 to 7 years: teaching guide. Kyiv : Shkilnyi svit; 2011. 128 p.

9 . Yurchuk 0 . Motor regime impact on physical state of preschool children. Nova pedahohichna dumka. 2017;2(90):64-8.

10. Andrieieva OV, Sainchuk OM. Approach to evaluating health level and adaptation possibilities in schoolchildren. Pedagogics, psychology, medical-biological problems of physical training and sports. 2014;2:3-8. doi: 10.6084/ m9.figshare.923507

11. Aubert S, Barnes JD, Abdeta C, Nader PA, Adeniyi AF, Aguilar-Farias N, Tremblay MS et al. Global Matrix 3.0 Physical Activity Report Card Grades for Children and Youth: Results and Analysis from 49 Countries. Journal of Physical Activity and Health. 2018;15:215-273. DOI: 10.1123/ jpah.2018-0472

12. Chatzopoulos D, Doganis G, Kollias I. Effects of creative dance on proprioception, rhythm and balance of preschool children. Early Child Dev Care. 2018;189:1943-53. DOl: 10.1080/03004430.2017.1423484

13. Dos Santos GC, do Nascimento Queiroz J, Reischak-Oliveira Á, Rodrigues-Krause J. Effects of dancing on physical activity levels of children and adolescents: a systematic review. Complementary Therapies in Medicine. 2021;56:102586. DOI: $10.1016 /$ j.ctim.2020.102586

14. Schroeder K, Ratcliffe S, Perez A, Earley D, Bowman C, Lipman TH. Dance for health: An intergenerational program to increase access to physical activity. J Pediatr Nurs. 2017;37:29-34. DOI: 10.1016/j.pedn.2017.07.004

15. Sekendiz B. FIT FOR KIDS. ACSM's Health \& Fitness Journal. 2018:22:33-6. DOI: 10.1249/ FIT.0000000000000382 